\title{
THE CONTRIBUTION OF ISLAMIC SCIENTIST IN CIVILIZATION
}

\author{
(The Scientific Framework In Unity of Sciences Paradigm)
}

\author{
Mirza Mahbub Wijaya \\ Email: dewalast79@yahoo.com \\ UIN Walisongo Semarang
}

\begin{abstract}
Abstrac:
This paper discusses the contribution of Muslim scientists in developing civilization. This is analyzed using the lens of the unity of sciences. A scientist must always think, research, and make various efforts for the development of Islamic science in globalization. Through this method, the chosen strategy is to develop scientific integration that can be taken for the development of knowledge that has been unable to dialogue with religion. Paying attention to inter-scientific relations without sacrificing autonomy between each scientific discipline and paying attention to the religious dimension of the Indonesian nation. This paper is expected to contribute to developing theoretical frameworks and practical strategies in the development of science in Indonesia.
\end{abstract}

Keywords: Paradigm, Islamic Scholar, Islam and Civilization

\begin{abstract}
Abstrak:
Tulisan ini membahas mengenai kontribusi ilmuwan muslim dalam mengembangkan peradaban. Hal ini dianalisis dengan menggunakan kaca mata unity of sciences Seorang ilmuwan harus selalu berpikir, meneliti dan melakukan berbagai upaya untuk pengembangan ilmu pengetahuan keislaman di tengah arus globalisasi. Melalui cara demikian maka tugasnya Strategi pilihan diantaranya adalah mengembangkan integrase keilmuan yang bisa ditempuh untuk pengembangan ilmu pengetahuan yang selama ini kurang mampu untuk berdialog dengan agama. Memperhatikan relasi antarilmu tanpa mengorbankan otonomi antara masing-masing disiplin ilmu dan memperhatikan dimensi religius bangsa Indonesia. Tulisan ini diharapkan memberikan kontribusi dalam menyusun kerangka teori dan strategi praktis dalam pengembangan ilmu pengetahuan di Indonesia
\end{abstract}

Keywords: Paradigma, Ilmuwan Muslim, Islam dan Peradaban

\section{Introduction}

The key to the growth of science is in the hands of scientists. Therefore, a scientist cannot be passive. He is obliged to have a sense of responsibility and always think about how to make efforts to improve the abilities possessed by the citizens, this matter must also match the abilities of scientists in their field of specialization. Thus, science wants to live in the citizens' well, to give birth to a perfect country. Science from era to era continues to face growth, thoughts continue to be a flash of development along with an increasingly environmental life, the emergence of various cases classified as citizens is a challenge that 
must be answered and responded to by scientists creatively and productively that can be accepted by citizens universally.

Thus, humans should be aware of developing knowledge creatively and creatively in overcoming citizen problems, great solidarity with ethics. Not only does he develop his knowledge, he also wants to continue learning endlessly, the knowledge he has will continue to be sharpened and added. Because with that one wants to feel like a student and teacher. Seeing the progress of science, it seems that it will not be achieved until a nation has its scientific tradition. The West itself advances in science and makes a lot of contributions to world civilization because it has the spirit of a scientific tradition. Muslim philosophers have contributed a lot to achieving brilliant scientific advances and made very significant contributions to world civilization. This is due to the scientific tradition that was built and has different characteristics from the Western scientific tradition. ${ }^{1}$

Therefore, Indonesian people must develop science within the value that makes many scholars have perfect personalities in their thinking. Where his thoughts are always looking for inspiration and ideas to experience new phenomena, they are always sensitive to the justice upheld by the government against the people. Because in essence, humans are perfect and moral and have social solidarity, namely humans with character and responsibility.

Over time, the discovery of a scientific method that has an empirical and rational character has amazingly led to the advancement of science and technology (science and technology). Since then human life has entered a new era called the modern era. Along with the advancement of science and the sophistication of modern technology, the problems that arise and face humans (society) in the modern era are increasingly complex and complicated. ${ }^{2}$

In facing the flow of modernism, not a few Muslim scientists have been defensive by taking a conservative-static position. They forget the sources of creativity, namely ijtihad, and even proclaim seclusion. This Muslim scientific attitude will ultimately lead to a separation of revelation and reason, a separation of thought from action and culture, and even lead to scientific stagnation among them, so that the negative impact of the Islamic scientific model itself is no less dangerous than the concept of western science. ${ }^{3}$

1 Mahfud Junaedi and Mirza Mahbub Wijaya, Pengembangan Paradigma Keilmuan Perspektif Epistemologi Islam: Dari Perenialisme Hingga Islamisasi, Integrasi-Interkoneksi Dan Unity of Science (Jakarta: Prenadamedia Group, 2019), 227.

2 Mirza Mahbub Wijaya, Filsafat Kesatuan Ilmu Pengetahuan: Unity of Sciences Sebagai Format Integrasi Keilmuan UIN Walisongo (Semarang: Fatawa Publishing, 2019), 1.

${ }^{3}$ Mirza Mahbub Wijaya, "Paradigma Berpikir Guru Pendidikan Agama Islam Di Era Disrupsi," Progress 7, no. 2 (2019): 125. 
The existence of a dichotomy of science makes religion and general science like water and oil. In general, general sciences are studied and developed by public schools and universities. Meanwhile, the science of religion is studied and developed in Islamic boarding schools, madrasas, and religious colleges. Finally, the development of general sciences feels dry as if the moral and ethical values of human life, while the development of religious science feels very rigid and seems to be powerless to answer the problems of mankind on earth. $^{4}$

Islamic thought about nature during the Golden Age was for mankind to pursue nature to create God and use nature for the benefit of mankind. Nature can be used to provide food for mankind and its abundance will be distributed thoroughly to all people. All activities that harm humanity and in turn disturb nature are prohibited. Shifting the balance of nature is not taught, for example, killing unnecessary animals or transplanting plants can, in turn, lead to starvation due to lack of food. This thinking is an extension of the idea that humans have been placed on earth as representatives of God. ${ }^{5}$ Moreover, we have other problems. $\mathrm{n}$ fact, the vast majority of Muslims make a little contribution in the field of world science today. ${ }^{6}$

In its historical records, education is truly capable of building civilization, so that the existence of an Islamic education paradigm is a must. The Islamic world was once a center for science and technology and reached its peak during the Abbasid Caliphate. At that time all intellectual activities were based on religious values, the ultimate goal of all activities was to uphold religion, and a balance between religious disciplines and intellectual development in the educational curriculum. ${ }^{7}$

But unfortunately the advances in Islam at that time were not able to be properly continued by the next generation so that without realizing it, the Muslims had let go of their pioneering work. Until now, Western nations have easily taken and transferred the knowledge possessed by Muslims so that the control and ruler of science and technology is in the west. Now is the time for Muslims to carry out progressive reforms in Islamic education. It takes an Islamic education paradigm that covers philosophical issues in a broad sense. This is at the heart of the issues discussed in this article.

\footnotetext{
${ }^{4}$ M. Amin Abdullah, Islamic Studies Di Perguruan Tinggi: Pendekatan Integratif-Interkonektif, (Pustaka Pelajar, 2007), 92.

5 Yasmeen Mahnaz Faruqi, "Contributions of Islamic Scholars to The Scientific Enterprise," International Education Journal 7, no. 4 (2006): 392.

${ }^{6}$ Eric Chaney, "Religion and the Rise and Fall of Islamic Science Extremely Preliminary and Incomplete," no. May (2016): 2.

${ }^{7}$ Wijaya, "Paradigma Berpikir Guru Pendidikan Agama Islam Di Era Disrupsi," 128.
} 


\section{Method}

This type of research is library research or in other languages by conducting library studies. Not only that, this research uses 2 approaches, namely, philosophical and historical. This research was tried on books related to the subject matter discussed with the descriptiveanalytic method overriding the conceptions of the paradigm of thinking of teachers of Islamic learning today through philosophical studies. A philosophical approach is useful for studying the structure or basic assumptions of a theory or paradigm.

A rationalistic philosophical approach is defined as the use of a research methodology based on the philosophy of rationalism which argues that science is not only obtained from sensual empiricism but is also obtained from intellectual verstehen (description) of the expertise of logical argumentation which emphasizes empirical and as well. The rationalistic philosophical approach views that reality as understood by researchers, based on existing theories, and is analogous to the subject being studied. The paradigm used includes hermeneutic procedures or content analysis.

\section{Disscusion}

A. Paradigm of Science

Before talking further, it is necessary to first discuss what paradigm is? Thomas S. Kuhn in The Structure of Scientific Revolutions, explains "Paradigms, a term that relates closely to normal science ... examples which include law, theory, application, and instrumentations together, provide models from which spring particular coherent traditions of scientific research ". 8 Kuhn also explained that paradigm has the meaning of the whole constellation of beliefs, values, techniques, and so on which are shared by members of certain scientific societies, and if they are used as models or examples, they can replace the rules explicitly as a basis for solving lagging scientific problems. ${ }^{9}$

Kuhn was the first to popularize the term paradigm in the scientific revolution theory. The term paradigm is defined as examples of scientifically accepted practice, such as theoretical law, application, instrumentation that become models of coherent practical traditions in scientific research. Scientific activity that accepts a paradigm in

\footnotetext{
${ }^{8}$ Thomas S Kuhn, The Structure of Scientific Revolutions (Chicago and London: The University of Chicago Press, 1996), 10.

${ }^{9}$ Kuhn, 176.
} 
solving the various problems faced is called science in the normal phase (Normal Science) so that eventually various anomalies that arise give rise to crises. ${ }^{10}$

Basically, science and knowledge are different. There are several conditions for knowledge to be categorized as science. As follows:

1. Objective: the object of the target material/study material, the formal object, namely the point of view of a science's approach to its object.

2. Methods, namely certain procedures/ways of science in an effort to find the truth.

3. Systematic, science often consists of several elements but still constitutes one unit. There is a relationship, a linkage between one part and another.

4. Universal, science is assumed to apply as a whole, not covering a certain place or a certain time. Science is projected to be widely applicable. $^{11}$

Knowledge is essentially all that we know about a particular object, including science. So science is a part of knowledge known to humans in addition to various other knowledge such as art and religion. ${ }^{12}$ Rational activity means activities that use the mind's ability to reason, which is different from activities based on feelings or instincts. Based on curiosity and intellectual needs, humans carry out a series of rational thoughts and activities which in turn give birth to knowledge. Rational thought or human rationality is the main source of science. The seed of science in human society lies in man's constant endeavor to understand and dominate the world in which he lives utilizing rational thought. Rational thinking is an activity of thought that is carried out optimally, that is, it is endeavored critically (directed at efforts to obtain correct knowledge), logically (obeying logical principles), and systematic (compiling the results in a consistent and coherent framework of thought). ${ }^{13}$

Science is developed by scientists to attain knowledge or truth. From these two things, it is hoped that science can also bring understanding to humans about the

10 Junaedi and Wijaya, Pengembangan Paradigma Keilmuan Perspektif Epistemologi Islam: Dari Perenialisme Hingga Islamisasi, Integrasi-Interkoneksi Dan Unity of Science, 350.

${ }^{11}$ Abbas Hamami Mintaredja, Epistemologi (Yogyakarta: Gajah Mada, 1987), 4.

12 Jujun S. Suriasumantri, Filsafat Ilmu: Sebuah Pengantar Populer (Jakarta: Pustaka Sinar Harapan, 1987), 104.

${ }^{13}$ Paulus Wahana, Filsafat Ilmu Pengetahuan (Yogyakarta: Pustaka Diamond, 2006), 74. 
universe, the world around them, or now that it is also about the community, the environment, and itself. Based on this understanding, science can explain natural phenomena, societal events, or human behavior that need to be explained. An explanation can be a basis for forecasting which can then be the basis for controlling something. Finally, science is also directed at the goal of the application, namely to make various means that will help humans control nature or achieve any practical goal. Thus, science does not aim at a single, limited goal but at various goals that seem to be able to evolve in line with the thinking of scientists. ${ }^{14}$

According to Iqbal, quoted by Yusuf Suyono in his book Reformasi Theology, he said that humans are God's chosen creatures and His representatives on this earth, free, independent personal beings who are equipped with intelligence even though they are surrounded by barrier forces, beings are restless and keep looking, beings who is a permanent element in the order of existence with its ever-increasing creative energy, in determining its destiny and the destiny of this world it shares its share. In short, according to Iqbal, humans are two-dimensional beings who with all their creativities want to build the kingdom of God on this earth (khalifatullah), and with their spiritual elements where the ego is involved in living the life and freedom of the Last Ego Who guides him, wants to be a pious servant. ${ }^{15}$ This is the position of a scientist who feels he is a representative of God, so that all the abilities he has, he strives to be realized in a real form.

\section{B. What is a Scientist?}

In general, a Scientist is a person who carries out activities or activities about the scientific field. The term scientist is used to describe someone's activity to explore the problems of scientists as a whole and to issue ideas in scientific form as evidence of their work to the world and also to share the results of these investigations with the common people because they feel that the responsibility rests on their shoulders. There are several definitions of scientists including:

1. Scientist in the view of Mc Graw-Hill Dictionary of Scientific and Technical Terms, a person who has the training, ability, and desire to seek new knowledge, new principles, and new materials in a field of science.

\footnotetext{
${ }^{14}$ Wahana, 74.

${ }^{15}$ Yusuf Suyono, Reformasi Teologi (Semarang: RaSAIL, 2002), 144.
} 
2. The scientist definition put forward by Maurice Richer, Jr. expresses the following opinion, namely, of those who participate in science, in relatively direct and creative ways. ${ }^{16}$

A scientist is a person who carries out activities or activities in relation to the scientific field. The term scientist is used to describe someone's activity to explore the problems of scientists as a whole and to issue ideas in scientific form as evidence of their work to the world and also to share the results of these investigations with the common people because they feel that the responsibility rests on their shoulders.

From the Renaissance to the present modern century, science must be viewed in terms of its phenomenon, namely the dimensions of the scientific community, the dimensions of the process, the dimensions of the product, and the structural dimensions. Judging from the dimension of the scientific community, namely scientists, there have been major changes and developments. If the scientists of the Ancient Greek era consisted of philosophical individuals and medieval scientists consisted of monks who were bound by church dogma, then the scientists of the Renaissance era only obeyed universalism, communalism, directed and orderly, their science was disinterested and skeptical. directed and orderly. ${ }^{17}$

They view knowledge as a process that is something that has not been completed. They try to find discoveries through research, including examining previously established theories. Even with the development of science in modern times, the characteristics of the Renaissance are still ongoing. This can be seen from Van Melsen's description of the characteristics which are summarized as follows:

1. That science must methodically achieve a logically coherent whole.

2. That science must be selfless (according to the term above is disinterestedness).

3. That science is required to have dimensions of universality

4. That science is required to be objective in nature, and so that objectivity can be guaranteed science can be diversified by all scientific researchers. Because knowledge must be communicated.

5. Progression.

\footnotetext{
${ }^{16}$ The Liang Gie, Pengantar Filsafat Ilmu (Yogyakarta: Liberty, 2000), 95.

${ }^{17}$ Yusuf Suyono, Bersama Ibnu Rusyd Menengahi Filsafat Dan Ortodoksi (Semarang: Walisongo Press, 2008), 85 .
} 


\section{Can be used. ${ }^{18}$}

So scientists are not just to carry out scientific activities or look for ultimately true problems, but a scientist also has a responsibility to solve scientific problems and to account for something that results from his findings and publish throughout the world.

\section{The Character That Scientists Must Have}

\section{Behavior Before Thinking}

a) Open-minded

A critical thinker must have a broad view, be open, and free from presumptions. He will not belittle a new idea. He is open to other people's opinions. He believes that personal and group prejudice and hatred will hinder his objectivity and thus become a barrier for him to be critical. A critical thinker will indeed make guesses, but he will also try to test his guesses to find out the truth. A critical thinker will not belittle a new idea. He will appreciate any new ideas and test them before they are accepted or rejected.

b) Honest

On the face of it, honesty is often identified with truth. Since the main focus of a scientific thinker is truth, honesty is an absolute prerequisite. Honesty in critical thinking can be said to be parallel to objectivity, which is letting the object speak, not the subject, or the person who thinks. A critical thinker is obliged to report the data he has obtained, the results of his understanding, and his conclusions objectively. Without honesty, he will not achieve validity in his critical thinking procedure, and without validity, he will not arrive at the correct conclusion.

c) Curiosity

A critical thinker is required to have a high curiosity. When he sees the process of natural phenomena, social life, cultural phenomena, humanitarian events, and so on, he will be aroused to want to know more about what, how, and why about these events or symptoms. The urge to

\footnotetext{
${ }^{18}$ Suyono, 86.
} 
curiosity is not only by him responding silently and contemplatively, but also by searching for information through various sources and trying to find answers to his curiosity. This critical curiosity seeks to question how something exists, what is its essence, how something functions, and how it relates to other things, and so on. This curiosity is ultimately understanding. This curiosity is what is developed continuously in the fields of research, investigation, testing, exploration, exploration, and experimentation.

d) Skeptic

A critical thinker, in seeking the truth, will be cautious, doubtful, and skeptical. The term skeptic in this case does not have a negative connotation. The skeptic in this case means refusing to accept or doubt something until is clear the evidence and arguments that underlie a statement or thought. a critical thinker will investigate the evidence from one thought and look for its basics. it will carefully examine the data on which to base a conclusion as well as the arguments or evidence presented.

e) Optimistic

A critical thinker always has good hopes and never gives up. He will not say that something cannot be done, but will say "Give me a chance to think about it and try to do it". The complexity of the problem and the difficulty of stealing solutions is a challenge in itself for a critical thinker. These challenges can certainly be resolved with diligence, accuracy, and technical thinking.

f) Courageous

Being a critical thinker is essentially being brave. Critical thinking means having the courage to evaluate beliefs, knowledge, behaviors, and anything that was previously considered correct and must be true. Critical thinking behavior means having the courage to question everything that has been considered by society to be automatically correct. In history, there have been many critical thinkers who have dared to take risks for seeking the truth, discovering the truth, or accepting the truth. The courage of Copernicus, Galileo, and Socrates are well known. Copernicus 
and Galileo were exiled because they did not believe that the earth was the center of the universe (geocentric) and considered the sun to be the center (heliocentric). Socrates chose to die by drinking poison rather than accepting the wrong thing.

g) Patience and Tough

A critical thinker should have the patience to follow correct thinking procedures, techniques, and requirements. He must also be able and strong not to give up facing any difficulties while trying to find the truth. Also, he must also be able to refrain from anything that encourages saying something that is not true is true or vice versa. ${ }^{19}$

\section{Behavior in Thinking}

a. Speculative

What is meant by speculation here is the willingness to try to come up with various possible answers to solve the problem at hand. A critical thinker cannot be satisfied with one perspective or one alternative answer. He had to make several attempts. When a solution to a problem turns out to be irrelevant or inappropriate, then another solution must be proposed. A critical thinker must try to come up with suggested answers that can be used as solutions to problems. Speculation is the desire to keep trying and trying, so it can be said that the hallmark of a critical thinker is the willingness to speculate.

b. Willingness to be demanded by practice and ratio

Intellect and experience are two sources as well as the main tools in critical thinking. A critical thinker must first be willing to accept his experience and reason as an instrument in critical thinking. A critical thinker is required to believe in his common sense and factual experiences in his life. Willingness to be guided by both reason and experience means a willingness to be rational in thinking and a willingness to accept information obtained from daily experience, either directly or indirectly.

c. Willingness to accept

What is meant by a willingness to accept here is acceptance of data. Data is something that is given in the experience when objects are

\footnotetext{
${ }^{19}$ Fahruddin Faiz, Thinking Skill: Pengantar Menuju Berpikir Kritis (Yogyakarta: Suka Press, 2012), 12.
} 
observed, accepted as relevant evidence for a problem to be solved. Among the critical attitudes is the willingness to accept data as it is before it is interpreted with subjective judgments from a thinker. A willingness to accept this data is the same as a willingness to be objective. Objective means that the object is not the subject which is the authority or source of knowledge that is or is the source of the knowledge sought.

d. Ready to face mistakes

A critical thinker is essentially human. Readiness to face this error means realizing himself as an ordinary human being who may be wrong so that when he realizes the mistake he has made, he is ready to admit and accept what is truer and more appropriate.

e. Willingness to postpone the decision

When a problem seems unsolved and satisfactory answers have not been found, a critical thinker is required not to rush into decisions and conclusions. A critical thinker must be prepared to wait until relevant evidence and arguments are found before conclusions can be drawn. ${ }^{20}$

\section{Behavior After Thinking}

a. Tolerant

A critical thinker does not feel that he is the greatest. He is willing to admit that other people may have more knowledge, or that his opinion may be wrong. To add insight, he is willing to learn from others, compare his opinion with the opinions of others, and not impose an opinion on others. A critical thinker does not feel that he is the greatest. He is even willing to admit that other people may have more knowledge, so that their opinion may be wrong, while the opinion of other people may be right. He is willing to accept other people's ideas after being tested. He has a high tolerance or tolerance, far from being arrogant.

b. Temporary

A critical thinker is always required to realize that everyone has limitations, including thinking. therefore a critical thinker always puts all the results of human thought, including his thinking, in a "temporary" or "tentative" or "open" room. A critical thinker is required to be calm and

\footnotetext{
${ }^{20}$ Fahruddin Faiz, 14.
} 
dogmatic. This temporary nature means the willingness to accept new things, new evidence or arguments, or new conclusions that are more valid than previous arguments or conclusions. This temporary nature is not the same as the "all-relative" character, because what is meant by temporary is to believe in the truth of something before there is new evidence or a more valid conclusion, while the "all-relative" character means that all truths are not certain or all truths are. relatively. ${ }^{21}$

\section{Contribution of Scientists to Civilization}

A scientist has a responsibility that should be carried on his shoulders. Not only because he is a community member whose interests are directly involved in society, but what is more important is that he has a certain function in the survival of society. Its function as a scientist does not stop at individual study and science but also takes responsibility so that scientific products arrive and can be utilized by the community. ${ }^{22}$

Jacob Bronowski (18 January 1908-22 August 1974), a Polish-Jewish scientist who later became a mathematician, biologist, and historical scientist who moved from Germany to England in 1920 because of World War I and later became a British citizen, writes with very sharp about the importance that scientist must have moral responsibility. Bronowski reflects on the atrocities of World War II, especially the atomic bombing of Nagasaki and Hiroshima which killed millions of innocent citizens, and this is seen as the failure of science to protect humanity. ${ }^{23}$

In the tenth century various kinds of knowledge began to be filtered back into Europe by means of the Arabic translation of the Greek lore and the original Greek treatises. But also being transferred to Europe is an important contribution of scholars of the Islamic world. Modern science as we know it today works with theories and models that must be tested empirically, ranging from the fields of mathematics, astronomy and medicine. Muslims develop procedures for testing knowledge both empirically and logically. But an important characteristic of Islamic science is its experimental character. Islamic scientists are particularly interested in applied science,

\footnotetext{
${ }^{21}$ Fahruddin Faiz, 16.

${ }^{22}$ Suriasumantri, Filsafat Ilmu: Sebuah Pengantar Populer, 237.

${ }^{23}$ Yeremias Jena, Filsafat Ilmu Kajian Filosofis Atas Sejarah Dan Metodologi Keilmuan (Yogyakarta: Deepublish, 2015), 222.
} 
apparatus construction, testing theory by making observations, and analyzing results through mathematics. These ideas and procedures were all made available in Western Europe through the important works of Islamic scholars before the time of Galileo, Descartes, and Newton to whom they were largely attributed. So, how do Muslims catch up in terms of scientific advancement $?^{24}$

According to Qomar, quoted by Maftukhin. In a more applicable way, Qomar offers several agendas for scientists for the progress of the nation and state. The steps are: first, changing the tradition of normative thinking into a tradition of theoreticalapplied thinking. Normative traditions are not useless, but these thinking traditions tend to be passive and less productive. Changing the normative thinking tradition to a theoretical-applied-thinking tradition requires several steps, namely: theology to social philosophy then moving to social theory, and finally leading to social change. ${ }^{25}$

Second, changing the ideological thinking tradition into a rational thinking tradition. The tradition of ideological thinking, according to Qomar, boils down to one keyword, namely interests. The characteristics inherent in this thinking tradition are closed, partial, sectarian, claiming the truest, and closing the door to dialogue. Science development strategy should teach rational thinking. Rational thinking is an important characteristic of developed societies. The mechanism starts from "awareness prioritizing the truth," then towards "eliminating partiality," after moving towards "looking for the strongest basis (argumentation)," and finally "accepting and confirming a truth even though it is contrary to its ideology. ${ }^{26}$

Third, do not make Islamic thought sacred. The attitude of sanctification shows the absence of dynamics, the courage to observe, and even weakens creativity. The important aspect to do is turn it into constructive criticism. The tradition of criticism carried out with empathy is an important factor for progress. The mechanism starts with "analysis of thinking," then "finding weaknesses," then "finding weaknesses," followed by "delivering criticism," followed by "offering new thoughts as solutions," as the response is "ready to be criticized by others," and ends "preparing scientifically strong arguments in response to other people's criticism". ${ }^{27}$

\footnotetext{
${ }^{24}$ Faruqi, "Contributions of Islamic Scholars to The Scientific Enterprise," 289.

${ }^{25}$ Maftukhin, "Ilmuwan, Etika Dan Strategi Pengembangan Ilmu Pengetahuan Di Indonesia," Epistemé 10, no. 1 (2015): 217.

${ }^{26}$ Maftukhin, 217.

${ }^{27}$ Maftukhin, 218.
} 
Fourth, changing the tendency of the axiological thinking tradition to think epistemologically. The axiological thought tradition is characterized by a tendency to argue on elementary questions which consume only energy but do not contribute to progress. The axiological concentration on yields and values is less productive, so it is important to shift it into a process and method area. This aspect becomes the concentration of epistemological thought. This thinking can encourage construction science. Mastery of epistemological thinking is an important provision for solving problems faced, even possible to build knowledge. The steps that can be taken starting from "mastering philosophy," then "mastering epistemology," followed by "mastering the method (methodology)," which brings about "finding clumps of knowledge (knowledge)," and finally "formulating science." 28

Fifth, changing the thinking tradition that emphasizes mastery of the material to an emphasis on methodology. Mastery of the material is important, but not sufficient for building progress. Because it must be balanced with mastery of methodology. All developed countries are methodological nations. Efforts to formulate knowledge into science can be taken through the initial steps in the form of "study of scientific material," then followed by "search for development methods," which results in "discovery of new methods of development." This new method is then followed by "the application of new methods in developing science," and closed with "the development of scientific treasures." 29

Sixth, changing the inferior mentality to be superior in the framework of developing strategic thoughts. It takes courage to convey ideas in public as well as to dare to be criticized and tested for its validity by others. The main assets for doing this stage are courage and ability. The mechanism of this agenda starts from a "deep reflection on the fundamental problems faced by the people." After being taken seriously this step resulted in the "discovery of the concept of strategic thinking." If this can be done, the next step is "efforts to grow the courage to convey the findings of thoughts independently and responsibly." The culmination of this step is "the spirit of overcoming the problems faced by the people." ${ }^{30}$

A scientist will not morally allow the results of his findings to be used to oppress other nations even though the one who uses it is his own people. History has

\footnotetext{
${ }^{28}$ Maftukhin, 218.

${ }^{29}$ Maftukhin, 218.

${ }^{30}$ Maftukhin, 219.
} 
recorded that scientists rose up and took a stand against the politics of their government, which they thought violated humanitarian principles. It turns out that in matters concerning humanity scientists have never been neutral. They stand up and speak up when humanity needs them. Their voices are universal across groups, races, power systems, religions, and other social barriers. ${ }^{31}$

Seventh, changing the tradition of expressing thoughts orally into a written tradition. The written tradition is a tradition of an advanced society. The quality parameter of scientists is writing, not speech. The steps taken were started with determining the theme of the writing, then searching for theoretical and empirical data." Once fulfilled, it will usually "stimulate the emergence of ideas and identify them, then group (clustering) data and ideas, express the data and ideas in written form. The last two steps are reviewing and revising. ${ }^{32}$

Eighth, changing the tradition of conveying other people's thoughts into a tradition of conveying one's thoughts. To realize this idea, several steps that can be taken are the spirit of catching up with Westerners, followed by the step of measuring the quality of their thinking and research, then having a passion to match them, then the enthusiasm for deepening research. thought and research, after that the spirit of scientific argumentation, and ended with the spirit of offering alternatives to paradigmatic thinking.

Ninth, developing the socialization of thought from a local-national scale to an international scale. The mechanism is "compiling international quality writing," then "using English or Arabic", then "looking for publishers who are willing to publish in foreign publishers", then "publishing implementation" and ending with "international distribution". ${ }^{33}$

the role of the scientist becomes something imperative. It is he who has sufficient background knowledge to be able to put the problem into true proportions. Therefore he has a social obligation to convey it to the public in a language they can digest. Facing problems that they do not understand usually people take an extreme. On the one hand, they are mute because of their ignorance, while on the other they are radical and irrational. This latter attitude is reflected for example by the desire to

\footnotetext{
${ }^{31}$ Maftukhin, 220.

${ }^{32}$ Suriasumantri, Filsafat Ilmu: Sebuah Pengantar Populer, 239.

${ }^{33}$ Suriasumantri, 244.
} 
destroy the power generation system for whatever reason for its existence. The social responsibility of a scientist, in this case, is to provide the right perspective.

In the field of social responsibility ethics, a scientist no longer provides information but provides an example. He must appear in front of how to be objective, open, accepting criticism, accepting the opinions of others, being strong in a position he thinks is right, and if necessary, having the courage to admit mistakes. All of these characteristics, along with others not mentioned here, are ethical implications of the scientific process of finding the truth. During a situation where all values experience shock, a scientist must come forward. The knowledge he has is a power that will give him courage. Likewise in a developing society, he must act as an educator by providing role models.

\section{CONCLUSION}

As evidenced by its history, Islamic scientist have tried to uphold and develop values from their world view and Islamic civilization, even Western science does not negate the problems related to values. The unique characteristic of the development of science in Islam comes from its emphasis on the unity of religion with science, knowledge with values, physics, and metaphysics. It is its emphasis on the diversity of methods and the use of the correct means to attain the right ideals which give civilization its distinctive style, and harmony is of utmost importance. Thus a science must be based on universal religious values so that it can benefit mankind, science, and technology that is not based on religious values will bring destruction, damage, and misery to mankind.

The science which has such great benefits for human life is not misused in its use, so scientists (as actors of scientific activities) must have adequate moral attitudes in carrying out scientific activities, namely having a scientific attitude. And thus scientific activity can realize goals that have such valuable value to human life, namely to provide enlightenment in pursuing the truth in life in this world. In addition to the instrumental values that exist in science, it is necessary to work on optimally, the instrumental values that are pursued need to be directed and used to increasingly be able to realize other positive values that can support the development of human life in various fields and all its aspects.

\section{Refrences}


Abdullah, M. Amin. Islamic Studies Di Perguruan Tinggi: Pendekatan IntegratifInterkonektif,. Pustaka Pelajar, 2007.

Chaney, Eric. "Religion and the Rise and Fall of Islamic Science Extremely Preliminary and Incomplete," no. May (2016): 1-32.

Fahruddin Faiz. Thinking Skill: Pengantar Menuju Berpikir Kritis. Yogyakarta: Suka Press, 2012.

Faruqi, Yasmeen Mahnaz. "Contributions of Islamic Scholars to The Scientific Enterprise." International Education Journal 7, no. 4 (2006): 391-99.

Gie, The Liang. Pengantar Filsafat Ilmu. Yogyakarta: Liberty, 2000.

Jena, Yeremias. Filsafat Ilmu Kajian Filosofis Atas Sejarah Dan Metodologi Keilmuan. Yogyakarta: Deepublish, 2015.

Junaedi, Mahfud, and Mirza Mahbub Wijaya. Pengembangan Paradigma Keilmuan Perspektif Epistemologi Islam: Dari Perenialisme Hingga Islamisasi, IntegrasiInterkoneksi Dan Unity of Science. Jakarta: Prenadamedia Group, 2019.

Kuhn, Thomas S. The Structure of Scientific Revolutions. Chicago and London: The University of Chicago Press, 1996.

Maftukhin. "Ilmuwan, Etika Dan Strategi Pengembangan Ilmu Pengetahuan Di Indonesia." Epistemé 10, no. 1 (2015).

Mintaredja, Abbas Hamami. Epistemologi. Yogyakarta: Gajah Mada, 1987.

Suriasumantri, Jujun S. Filsafat Ilmu: Sebuah Pengantar Populer. Jakarta: Pustaka Sinar Harapan, 1987.

Suyono, Yusuf. Bersama Ibnu Rusyd Menengahi Filsafat Dan Ortodoksi. Semarang: Walisongo Press, 2008.

- Reformasi Teologi. Semarang: RaSAIL, 2002.

Wahana, Paulus. Filsafat Ilmu Pengetahuan. Yogyakarta: Pustaka Diamond, 2006.

Wijaya, Mirza Mahbub. Filsafat Kesatuan Ilmu Pengetahuan: Unity of Sciences Sebagai Format Integrasi Keilmuan UIN Walisongo. Semarang: Fatawa Publishing, 2019.

—. "Paradigma Berpikir Guru Pendidikan Agama Islam Di Era Disrupsi." Progress 7, no. 2 (2019): 123-47. 